Original Research Paper

\title{
Policy Priorities for the Economic Development in Agropolitan Area of Karacak Based on Mangosteen Agroindustry
}

\author{
${ }^{1}$ Parwa Oryzanti, ${ }^{1}$ Ernan Rustiadi, ${ }^{1}$ Eriyatno and ${ }^{2}$ Nurul Taufiqu Rochman \\ ${ }^{1}$ Bogor Agricultural University, Bogor, West Java, Indonesia \\ ${ }^{2}$ Indonesian Institute of Sciences, Jakarta, Indonesia
}

Article history

Received: 01-11-2018

Revised: $14-12-2018$

Accepted: 3-01-2019

Corresponding Author:

Parwa Oryzanti

Bogor Agricultural University,

Bogor, West Java, Indonesia

Email: riceoryzanti@gmail.com

\begin{abstract}
Agropolitan approach is important in connecting rural and urban development areas at the local level. Efforts need to be continuously carried out in the development of agropolitan region which is essential for accelerating rural development in general and agriculture in particular. This study was conducted in agropolitan area of Karacak, Bogor District, Indonesia, by using the judgement of experts. The type of data used was primary data collected through expert surveys. Data analysis was performed with Analytic Hierarchy Process (AHP) approach using Expert Choice software. Mangosteen as strategic commodity in the region, have not been developed for agroindustrial scale. Agroindustrial approach is important, to encourage economic growth in the agropolitan area, through increasing the economic value of strategic commodity. The introduction of agro-industry into agropolitan area requires policy support. The purpose of this study was to determine the priority of economic development policies in agropolitan area of Karacakbased on mangosteen agro-industry. The results showed that the main direction related to economic development policy of agropolitan area based on agro-industry, was the policy of providing incentives for agro-industrial investors in the agropolitan area with alternative weights 0.319 . The main actor was the private sector (investors) with criteria weight 0.263 . Whereas, the main objective was to encourage investor's interest to invest in agropolitan area with criteria weight 0.402 .
\end{abstract}

Keywords: Agropolitan Approach, Agroindustry, Development Policy, Mangosteen

\section{Introduction}

According to Friedmann and Douglass (1975), the agropolitan approach as development activities concentrated in rural areas with population between 50,000 and 150,000 people. Both also emphasized the importance of an agropolitan approach in rural development in the Asia and Africa region. Then, Douglas (1998) argues that rural development through the development of agropolitan concepts emphasizes the importance of linking or connecting rural areas with urban development at the local level.

According to Douglass (1998), rural-urban linkages can at least be described in five main forms of linkages, namely (1) people/population, (2) production, (3) commodities, (4) capital and (5) information. Whereas according to Rondinelli (1985), linkages can be grouped into physical, economic, technological, population movement, social relations, service delivery and various political relations. One of the interesting things from Rondinelli's opinion is that there is an element of political relations. As a result of the weakness of rural institutions in terms of access to political decisions, ultimately political control is dominated by cities.

Agropolitan development is aimed to increase agricultural production and to sale agricultural products, supporting the growth of small-medium scale agroindustries and to encourage diversity of economic activities from the market centers (Rustiadi and Dardak, 2008). So, how to increase the economic value of agricultural commodities to support the sustainability of agropolitan area becomes important. Increasing economic value for strategic commodity is taken by 
processing it into products that have higher value and competitiveness, known as agricultural industry (agroindustry). Austin (1981) defines agro-industry, which is a company that processes some materials from plantbased (plant-derived) or animal-based (which are produced by animals). The process used including conversion and preservation through physical or chemical treatment, storage, packaging and distribution. Furthermore, according to Mangunwidjaja (1993), the development of agro-industry can be a strategic choice in overcoming economic problems and alleviating poverty in rural areas. Agro-industry development based on rural communities is an appropriate sector to accommodate a large number of workers and ensure expansion of business, so that it will be effective in efforts to improve the economy of rural communities.

This research was conducted by case study in agropolitan area of Karacak. Administratively, it is located in the village of Karacak, Leuwiliang district, Bogor regency, West Java, Indonesia. Geographically, Karacak village is located at 106039'00 "-106036'00" East Longitude and 06039'00 "-06034'30" South Latitude and has 761.84 ha. Leuwiliang district was included in the strategic commodity development zone through the development of agropolitan areas. Karacak village is one of the villages in Leuwiliang district and is a part of the Bogor Regency Agropolitan Area as a pilot for the development of the Agropolitan Program in 2005 (Bappedalitbang, 2017). The problem is that mangosteen as strategic commodity in the region, has not developed into various processed products in the scale of agro-industry.

Mangosteen (Garcinia mangostana L.) is included in the Guttiferae family. The fruit is red to dark purple, the edible part is white, soft and lots of water (juicy), it tastes sweet with a little sour and pleasant aroma (Jung et al., 2006). The mangosteen peel has a slippery and hard surface. Mangosteen rind is rich in pectin, tannins, black substances and antibiotic xanthones (Verhej and Coronel, 1997). Mangosteen is known as the Queen of Tropical Fruit (Popenoe, 1974). Mangosteen trees in Indonesia are harvested from November to March of the following year. Production of one hectare (100 plants) can reach 200.000 peaces or around 20 tons of fruit. Mangosteen is one of the primary strategic commodities of Bogor Regency in 2016, with production 79.927 tons (BPS, 2016).

According to Kastaman (2007), based on the characteristics of the fruit, mangosteen can be processed into various processed products such as juice, xanthone juice from mangosteen, fruit syrup, cocktails, capsules or xanthone tablets which are beneficial for health, anticancer drugs, diet supplements, or coloring material. The agroindustry approach based on mangosteen is important, to encourage economic growth in the agropolitan area of Karacak, through increasing the economic value of mangosteen processed products.
However, the introduction of agro-industries into agropolitan areas requires policy support.

In the context of regional development, there are several development policies that continue to evolve as science advances and the dynamics of the problems faced. Broadly speaking, the policy can be classified into three groups, namely: (1) Development policy from above (Hansen, 1981); (2) development policies from below (Stohr, 1981); and (3) local economic development policies (Blakely, 1991). Basically, the top policies complement and perfect each other according to the situation, conditions and problems that occur. In accordance with the stage of its existence, the policy that emerged later was a reaction and criticism of the previous policy. The development top policy has weaknesses because it can cause gaps in smaller regions due to the exploitation of resources by larger regions. Meanwhile, the development buttom policy actually has a pretty good content but is often weak in implementation, so this policy tends to be utopia. Finally, the local economic development policy (Blakely, 1994) can be considered as an alternative to solve problem that occur in development top policies and development buttom policies.

In the context of agropolitan development, in general there are 3 (three) main issues that need attention: (1) access to agricultural land and water, (2) political devolution and administrative authority from the central level to the local level of government and (3) paradigm changes or national development policies to support diversification of agricultural products. Furthermore, Rustiadi et al. (2009) stated that by looking at the cityvillage as the main site for political functions and administrative, agropolitan development in many countries was more suitable to be create at district scale.

In agropolitan concept, through the support of human resources, technology, production facility, land suitability and infrastructure systems, the role of villages and cities can be proportional, synergistic and mutually reinforcing. The importance of the agropolitan program is expected to provide broad benefits (multiplier effect), especially from the ecology-socio-economic side of the community.

Various efforts need to be carried out constantly considering the development of agropolitan area is very important for the acceleration of rural development and agriculture. According to Rustiadi and Dardak (2008) an agropolitan area that has developed has characteristics, namely; (a) most of the people in the area receive income from agricultural activities (agribusiness), (b) most of the activities in the area are dominated by developing agricultural or agribusiness activities, including agricultural industries, trade for agricultural products including trade for export activities, trade for upstream agribusiness (agricultural facilities, capital) in small scale industries and agrotourism and service, (c) the relationship between cities and agropolitan areas is interdependence/reciprocity in harmony and need each other, where the agropolitan area develops a cultivation 
business (on farm) and processed products on a household scale, whereas the city provides facilities for developing agribusiness such as providing of agricultural facilities, capital, technology, output processing and product storage (marketing)information, (d) lifestyle of society in agropolitan area is similar to the atmosphere of the city because the conditions of the facilities in agropolitan area is the same with the city.

At the end of the program, it is expected that in the agropolitan area will grow agroindustries based on strategic commodity that produce products that have competitiveness and can prosper the society. Austin (1992) asserts that agroindustry is able to make a real contribution for development in most developing countries. Agroindustry development in agropolitan areas involves many related elements and interact each other. Therefore, an assessment of the direction for economic development policy in agropolitan area based on agroindustry, was through system approach. Definitively, a system is a group of elements that are interconnected each other and organized to achieve a goal or a cluster of goals (Manetsch and Park, 1979). Furthermore, Eriyatno (1999) suggested that the system approach is a problem-solving method that begins with identification and needs analysis and ends with the results of an effective and efficient operating system.

\section{Material and Methods}

\section{Description of the Study Sites}

The study was conducted in the agropolitan area of Karacak, Bogor District, Indonesia. The research was carried out with experts judgement.

\section{Types and Sources of Data}

The type of data used in the study of the direction of economic development in agropolitan area of Karacak, Bogor District, was primary data. Primary data is data obtained directly from the field/object of research, either in the form of measurements, observations or interviews (Nazir, 1988). Meanwhile, according to Nasution (2011) primary data is data obtained directly from the source and recorded for the first time. The primary data source in this study came from experts opinion/judgement which was the representation from stakeholders.

\section{Method of Data Collection}

Data collection method is a technique used to collect data (Sugiyono, 2010). Data collection method for the study of the direction of economic development in agropolitan area of Karacak, Bogor District, was carried out with experts survey. Survey research is one of the research approaches that is generally used for extensive and numerous data collection and is carried out on large and small populations, but the data from samples taken from the population. Furthermore, it is stated that survey research is a data/information collection technique that is carried out by compiling a list of questions submitted to respondents. The purpose of survey research is to obtain information on opinions from respondents directly.

The interview technique used in this research was structured interview technique, which was performed by using a closed and open questions in the form of questionnaire. According to Arikunto (2006), questionnaire is a written statement that is used to obtain information from respondents in the sense of a report about a person or things that are known. Whereas, according to Sugiyono (2008) questionnaire is a data collection technique that is performed by giving a set of questions or written statements to respondents to be answered. The questionnaire developed in this study was a closed questionnaire. Closed questionnaires were developed to obtain experts judgement. This data collection method approach was expert based, therefore the respondents who were the target of questionnaire were those who identified as experts with criteria, namely; (1) expertise in the academic or research level, (2) expertise as policy makers, (3) special expertise such as; local wisdom. Experts consisted of 5 (five), this accordance to Hora (2004) stating that the number of experts who are adequate and have high precision are as many as 3 to 6 or 7 people. Questionnaires were developed using pairwise comparison method with ordinal data types using Saaty (1993). The use of scale of Saaty (1993) was carried out by pairwise comparison techniques, in which each pair would be paired in comparison with a rating scale of 1 to9. As a basis for compiling the pairwise comparison questionnaire structured/hierarchical/level of the study were carried out with the following details.

\section{Method of Data Analysis}

Methods of data analysis on the study of the direction of economic development policy in agropolitan area based on mangos teen agroindustry, were carried out using the Analytic Hierarchy Process (AHP) approach. AHP is a decision support model developed by Thomas L. Saaty. This decision support model will describe complex multi-factor or multi-criteria problems into a hierarchy/level. According to Saaty (1993), hierarchy is defined as a representation of a complex problem in a multi-level structure where the first level is the purpose/focus, followed by the next level, namely criteria, sub-criteria and so on to the last level i.e. alternative. Furthermore, it is stated that AHP is a decision-making method that involves a number of criteria and alternatives that are selected based on the consideration of all related criteria in the form of hierarchy. With a hierarchy, a complex problem can be broken down into groups that are then arranged hierarchically so that the problem will look more structured and systematic. According to Marimin (2004), AHP has many advantages in explaining the decision making process, because it can be described graphically, therefore it is easily understood by all parties involved in decision making. 


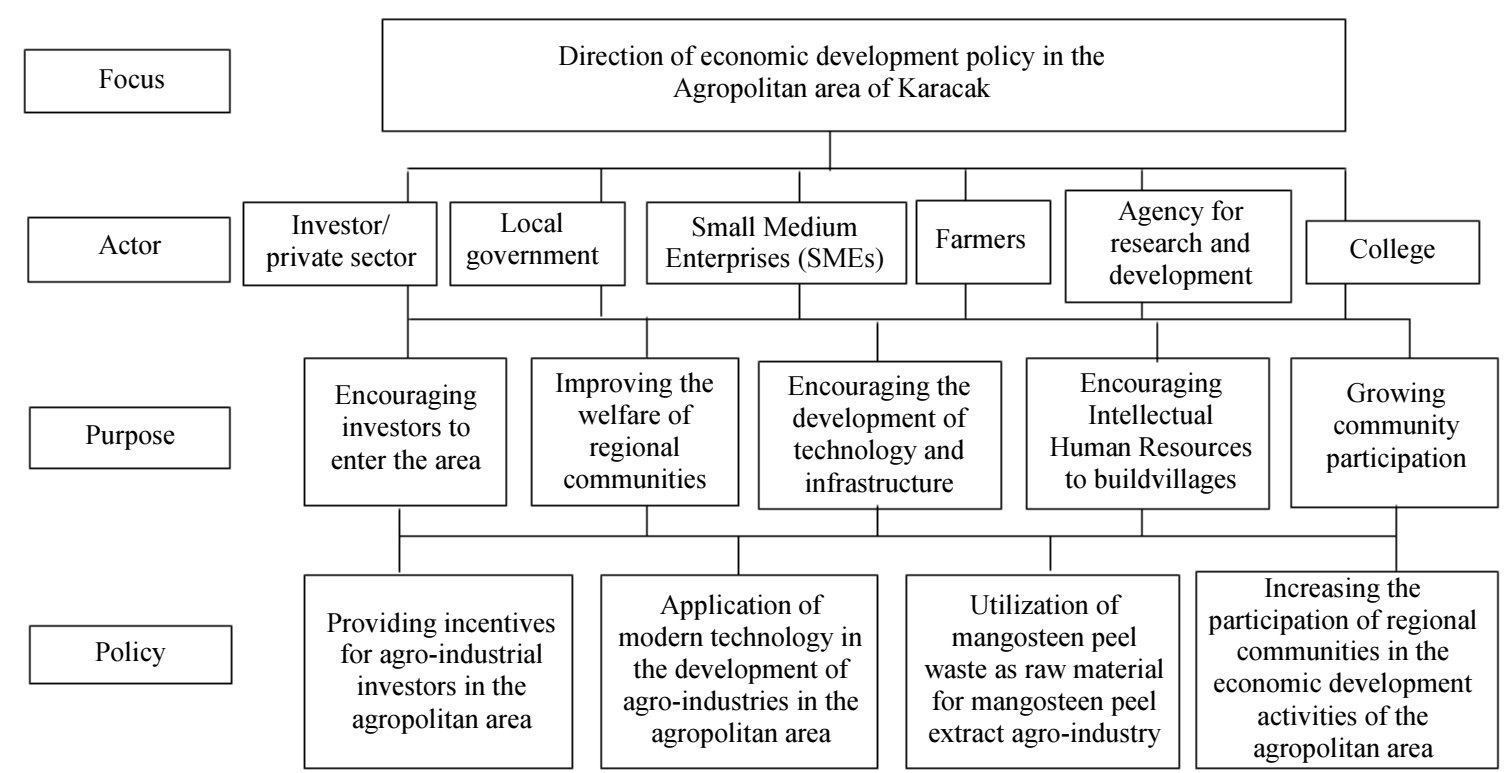

Fig. 1: Hierarchy structure for the economic development in the Agropolitan Area of Karacak

AHP's operational stages in the study of economic development policy in agropolitan area of Karacak based on agroindustry, as follows:

- Creating and structuring hierarchical structures, including; focus, actor, pupose and policy that was compiled as shown in Fig. 1.

- Defining focus/purposes/goals, namely; priority of economic development in agropolitan area of Karacak.

- Defining criteria of actor namely; Investors/private sector, Local Government, SMEs, Farmer, Agency for research and development and College.

- Defining purposes criteria, namely; (a) Encouraging investors to enter the area, (b) Improving the welfare of regional communities, (c) Encouraging the development of technology and infrastructure, (d) Encouraging Intellectual Human Resources to build villages and (e) Growing community participation

- $\quad$ Determining the policy alternatives, namely; (a) Providing incentives for agro-industrial investors in the agropolitan area, (b) Application of modern technology in the development of agro-industries in the agropolitan area, (c) Utilization of mangosteen peel waste as raw material for mangosteen peel extract agro-industry and (d) Increasing the participation of regional communities in the economic development activities of the agropolitan area

- Constructing a pairwise comparison matrix that describes the relative contribution or influence of each element on the criteria that are level above it.
- $\quad$ Running the software of Expert Choice

Expert Choice is software that can be used to solve problems based on the Analytic Hierarchy Process (AHP) method, which compares many alternatives with certain criteria. Expert Choice provides tools including analysis of decision making, giving faster decisions, better and justifiable final decisions. Expert Choice is used as a tool for implementing models in the Decision Support System (DSS). Some conveniences are found in the Expert Choice compared to similar softwares, including: Graphical User Interface (GUI) facilities, which are available, therefore they are easy to apply, both for beginners and experts. It has many features that provide a good Decision Support System modeling, without the need to reset many parameters. This software can be used to determine decisions that are difficult to decide by decision makers. This software has a high level of accuracy for AHP method, when supported with consistent data and has output validation in the form of ratio consistency criteria. According to Saaty (2008), if the Consistence Ratio (CR) value is less than $10 \%$ then the results can be called consistent. And if the $\mathrm{CR}$ value is greater than or equal to $10 \%$, then the results are inconsistent and the paired matrix must be reconstructed.

\section{Results and Discussion}

The results showed that policy (in level 3) which was a top priority related to economic development in agropolitan of Karacak was policy of providing incentives for agro-industry investors in the agropolitan region with alternative weights 0.306 . The policy, mainly was to encourage investor interest in entering 
and investing in the agropolitan area of Karacak which was a priority goal (in level 2) with criterion weights 0.402 . To support the implementation of priority policies and achieve goals, based on analysis, actors (in level 1) who had a priority role, namely the private sector, in this case investors were the main priority as actors with criterion weights 0.263 .

\section{Priority of Policy}

The results showed that the main priority of the agropolitan economic development policy for Karacak was the policy of providing incentives for agro-industry investors in the agropolitan area with the highest alternative weights 0.306 as shown in Fig. 2. The second alternative was the application of modern technology in the development of agro-industries in the agropolitan area with alternative weights 0.288 . The next alternative was the use of mangosteen peel waste as an agro-industrial raw material with alternative weights 0.212 ; and increasing the participation of the regional community in agropolitan economic development activity with alternative weights 0.194 . These results could be accepted considering the value of consistency ratio was 0.04 or less than $10 \%$. The following were policy priorities in the direction of the economic development of the agropolitan area Karacak.

Determination of various policy directives in the development of the agropolitan area becomes very important. According to Rustiadi and Hadi (2006), the integrated agropolitan area development requires a master plan for development program reference. The master plan include: (a) Establishment of an agropolitan center that functions as a center for agricultural trade and transportation, provide of agricultural support services, consumer market for non-agricultural products, agroindustrial center, non-agricultural employment center and the agropolitan center for hinterland related to national, provincial and district settlement systems, (b) Determination of development area units that function as centers of agricultural production, agricultural intensification, centers of rural income and demand for non-agricultural goods and services as well as production of ready-to-sell crops and agricultural diversification, (c) Determination of leading sectors that have been developed and supported by the downstream sector, agribusiness activities that involve the largest number of actors and communities and have economies of scale that allow for export-oriented development, (d) Infrastructure support for the development of agropolitan area includes road networks, irrigation, water resources and utility networks (electricity and telecommunications), (e) Institutional system support is the manager of the development of agropolitan area which is part of the regional government with central government facilities and the development of an institutional system of incentives and disincentives, the development of the agropolitan area. Through these links, agropolitan centers and rural areas interact each other profitably.

The direction of the policy to provide incentives for agro-industrial investors in the agropolitan area would be priority in agropolitan area of Karacak development. Incentives can be provided related to tax relief, compensation, rewards, space rent, stock reduction, infrastructure provision, ease of licensing procedures, or awards and other access including business space incentives in accordance with zoning plans arranged in the master plan.

According to Anderson (1979), the policy alternative is the formulation of policy proposals which are activities to compile and develop a series of actions that need to be done to solve problems or to achieve goals. Meanwhile, Mustopadidjaja (1992) stated that policy alternatives are a number of tools or ways that can be used to achieve, directly or indirectly a number of predetermined goals and objectives. More detailed according to Dunn (2003), policy alternatives are the direction of potentially available actions that can contribute to the achievement of values and problem solving policies.

\title{
Priorities with respect to:
}

\author{
Direction of the Economic Development in the Agropolitan Area of Karacak \\ $>$ Policies
}

Providing incentives for agro-industrial investors in the agropolitan area Application of modern technology in the development of agro-industries Utilization of mangosteen peel waste as material for agro-industry Increasing the participation of regional communities in every activity

Inconsistency $=\mathbf{0 , 0 4}$

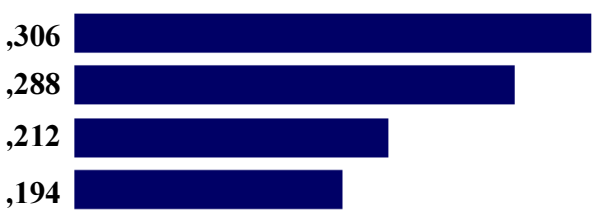

Fig. 2: Priority of policy for the economic development in agropolitan area of Karacak 


\section{Priority of Actor}

Actors or stakeholders are all parties involved in the development of the agropolitan area Karacak. Freeman and Gilbert (1995) define stakeholders as groups or individuals who can influence and/or be influenced by an achievement of certain goals. In this study the main stakeholders in the agropolitan economic development based on agro-industry include: (1) Private sectors; (2) Local Government; (3) SMEs; (4) Farmers; (5) Agency for research and development; and (6) Colleges. The results of the analysis showed that the private sector in this case is the investor was the main priority as an actor in the economic development of the agropolitan area Karacak with a criterion weight of 0.263 as shown in Fig. 3. The second priority is SMEs $(0.216)$. The next priority was Farmers (0.201), Agency for research and development (0.141), Local Government (0.096) and Colleges (0.084). These results could be accepted considering the value of consistency ratio was 0.06 or less than $10 \%$. Following are the priorities of the actors in the direction of the economic development in agropolitan area of Karacak.

Investors were the main actors in the economic development of Karacak agropolitan area. According to Hill and Jones (1992), actors or stakeholders are people with an interest or attention to problems. The presence of investors (private sectors) will greatly assist in the economic development of Karacak agropolitan area. The presence of these investors is to invest, therefore there is a capital flow to grow the regional economy. According to Sunariyah (2003), investment is to invest capital in one or more assets owned and usually long-term in the hope of gaining profits in the future. Meanwhile, according to Sukirno (1994), investment is the expenditure of investment or companies to buy capital goods and production equipment to increase the ability to produce goods and services available in the economy. Capital as a factor of production is an important component in economic growth.
According to Arsyad in Sihombing (2008), capital formation is the key to economic growth, the only major obstacle that can hinder the occurrence of economic development is the limited capital accumulation therefore the need for initial capital to stimulate the emergence of new domestic flows therefore the dependence on external assistance long-term can be minimized. The existence of capital accumulation can enable increased output and income in the future, so as to increase economic growth. According to Todaro and Smith (2015), the things that make possible an increase in output in the future are the procurement of new factories, machinery, equipment and raw materials that increase the stock of physical capital of country (i.e., the net real total of all productive capital goods physically). These direct productive investments must be complemented by various supporting investments called economic and social infrastructure such as the construction of highways, electricity supply, clean water supply and sanitation improvements, construction of communication facilities, etc., all of which are absolutely necessary in order to support and integrating all productive economic activities.

\section{Priority of Purpose}

The results showed that the purpose of encouraging investor's interest in the area and do investment was a top priority in agropolitan economic development with criterion weights 0.402 as shown in Fig. 4. This value was the highest compared to other criteria. Other criteria are to encourage the development of regional technology and infrastructure $(0,266)$; encourage intellectual human resources to build villages (0.119), improve regional community welfare $(0.11)$ and foster regional community participation (0.103). These results could be accepted considering the value of consistency ratio was 0.01 or less than $10 \%$. The following were priority purpose related to the economic development of the agropolitan area Karacak.

Priorities with respect to:

Direction of the Economic Development in the Agropolitan Area of Karacak

$>$ Actors
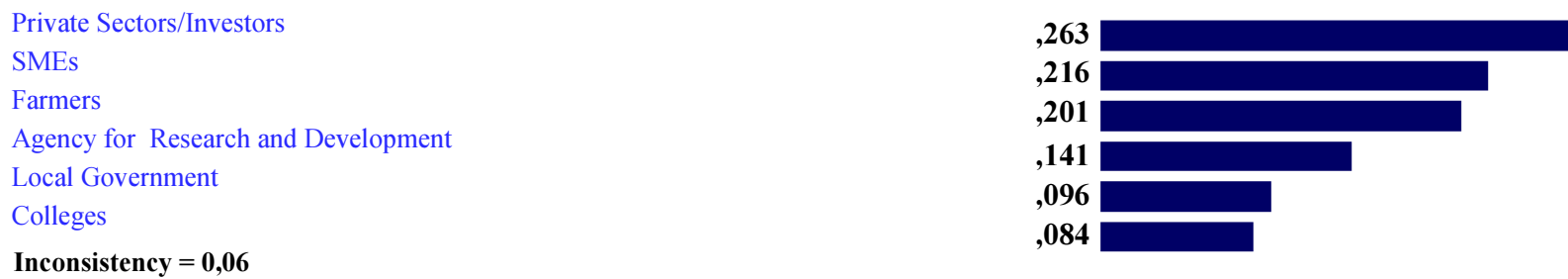

Fig. 3: Priority of actor for the economic development in Agropolitan area of Karacak 

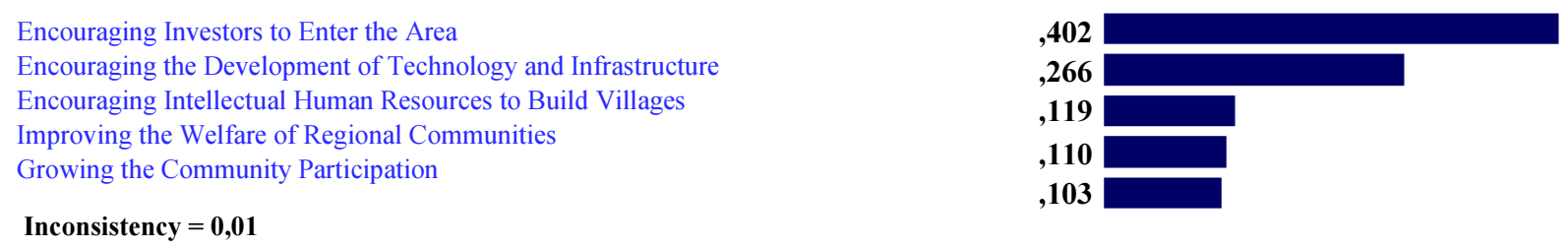

Fig. 4: Priority of purpose for the economic development inagropolitanarea of Karacak

The main purpose of developing the Karacak agropolitan area was to encourage investor's interest do investment. The investor's interest needs to be encouraged through various economic policies, especially related to policies that provide ease in investing, such as; ease of licensing, access to information and various other incentives. To encourage the interest of investors, various strategies are needed. Investor's interest in investing in an area or sector is strongly influenced by various factors including national political and economic factors as well as other social factors such as conflict-prone areas, availability of labor, wage issues, accessibility issues and various other factors.

According to BKPM (2015) a Capital Investment Coordinating Board of the Republic of Indonesia, there are several internal and external factors which are obstacles to increasing investment in Indonesia, including; (1) Internal factors, those are: (a) Social, political and security stability are not conducive to investment (b) Enforcement and legal certainty are still lacking (c) There is no clarity on the authority to handle investment in the era of regional autonomy (d) Bank interest rates are still quite high (e) One roof service system is not yet running (f) Less competitive fiscal incentive policy (g) Inadequate infrastructure especially in Eastern Indonesia and (h) Problems in relation to the implementation of Regional Autonomy; (2) External factors include: (a) Commencement of trade and investment liberalization in developing countries in the Asia Pacific region (AFTA 2002; AIA 2003; APEC 2020) (b) Competition between countries in attracting increasingly sharp Foreign Direct Investment (FDI) and (c) There are still negative perceptions of Indonesia's investment competitiveness and climate.

\section{Conclusion}

The priority policy for economic development in the agropolitan area of Karacak based on mangosteen agroindustry, was providing incentives for agro-industry investors in the agropolitan area. The policy was driven by the main actors, namely the private sector (investors), in order to encourage investors enter the area and do investment for economic development in agropolitan area.

\section{Acknowledgement}

The author sincerely thanked all parties related to this research, namely: Experts who have provided opinions in expert surveys for AHP analysis, Ministry of Technology Research and Higher Education of the Republic of Indonesia through the 2018 INSINAS Program which has partially funded this research process, Bogor Regency Regional Government and related institutions, PT Zena Nirmala for cooperation in mangosteen-based agroindustry studies.

\section{Author's Contributions}

This research was carried out jointly by all authors. The author Parwa Oryzanti wrote all draft of the research results, made the initial design and analyzed with AHP. Furthermore, the writer Eriyatno gave direction and review of the entire draft. Author Ernan Rustiadi and Nurul Taufiqurochman provide direction related to the research.

\section{Ethics}

The authors have not declared any conflict of interests.

\section{References}

Anderson, J.E., 1979. Public Policy Making. 2nd Edn., Chicago, Holt, Rinehart and Winston.

Arikunto, S., 2006. Prosedur penelitian, suatu pendekatan praktek. PT. Rineke Cipta. Jakarta.

Austin, J.E., 1981. Agroindustrial project analysis. EDI Series in Economic Development. Washington DC (US). Washington Pr.

Austin, J.E., 1992. Agroindustrial project analysis critical design factors: EDI series in economic development. John Hopkins University Press, Baltimore. 
BPS, 2016. Kabupaten Bogor dalam Angka. BPS Kabupaten Bogor, Bogor.

Bappedalitbang, 2017. Badan perencanaan pembangunan, penelitian dan pengembangan daerah kabupaten Bogor. Penyusunan Dokumen Rencana Pengembangan Kawasan Agropolitan. Bappedalitbang Kabupaten Bogor, Bogor.

BKPM, 2015. Upaya debottlenecking dalam mengatasi Masalah Investasi. Badan Koordinasi Penanaman Modal Indonesia, Jakarta.

Blakely, E.J., 1991. The meaning of local economic development. Local economic development. ICMA, Washington.

Blakely, E.J., 1994. Planning local economic development: Theory and practice. Sage Publications.

Douglass, M., 1998. A regional network strategy for reciprocal rural-urban linkages: An agenda for policy research with reference to Indonesia. Third World Plann. Rev., 20: 1-25.

Dunn, W.N., 2003. Public Policy Analysis: An Introduction. Prentice Hall.

Eriyatno, 1999 Ilmu Sistem: Meningkatkan Mutu dan Efektivitas Manajemen. Jilid Satu. Bogor. IPB Pr.

Freeman, S. and Gilbert, 1995. Pengantar Bisnis. Graha Ilmu, Yogyakarta.

Friedmann, J. and Douglass M., 1975. Agropolitan Development : Towards a New Strategy for Regional Planning in Asia. Los Angeles: School of Architecture and Urban Planning, University of California.

Hansen, N.M., 1981. Development from above: The center down developmet paradigm. The Dialectics of Regional Planning in Developing Countries, John Willey and Sons, Chichester.

Hill, C.W.L. and T.M. Jones, 1992. Stakeholder-agency theory. Manage. Stud., 29: 131-154.

Hora, S.C., 2004. Probability judgments for continuous quantities: Linear combinations and calibration. Manage. Sci., 50: 597-604.

Jung, H.A., B.N. Su, W.J. Keller, R.G. Metha and A.D. Kinghorn, 2006. Antioxidant xanthones from the pericarp of Garcinia mangostana (Mangosteen). Agric. Food Chem., 54: 2077-2082.

Kastaman, R., 2007. Analisis prospektif pengembangan produk olahan manggis dalam upaya meningkatkan pendapatan petani. Laporan Kajian pengembangan komoditi Manggis. Kerjasama LPM UNPAD dengan Direktorat Jenderal P2HP Departemen pertanian.

Manetsch, T.J. and G.L. Park, 1979. System analysis and simulation with application to economic and social science. Michigan State University, East Lausing, USA.

Mangunwidjaja, D., 1993. Pengembangan teknologi proses untuk agroindustri. Makalahpada Forum Teknologi, Dikti, Depdikbud, Bogor.
Marimin, 2004. Teknik dan aplikasi pengambilan keputusan kriteria majemuk. IPB Press dengan Program Pascasarjana IPB, Bogor.

Mustopadidjaja, A.R., 1992. Studi kebijaksanaan, perkembangan danpenerapannya dalam rangka administrasi dan manajemen pembangunan. LP-FE UI, Jakarta.

Nazir, 1988. Metode penelitian. Ghalia Indonesia, Jakarta.

Nasution, 2011. Metode research penelitian ilmiah. PT Bumi Aksara, Jakarta.

Popenoe, W., 1974. Manual of Tropial and Subtropical Fruit. 2nd Edn. Hafner Press, New York.

Rustiadi, E., S. Saefulhakim and D.R. Panuju, 2009. Perencanaan dan pengembangan wilayah. Yayasan Obor Indonesia, Jakarta.

Rustiadi, E. and Dardak, 2008. Agropolitan (Strategi Pengembangan Pusat Pertumbuhan pada Kawasan Perdesaan). Crestpent Press, IPB Bogor.

Rustiadi, E. and S. Hadi, 2006. Pengembangan Agropolitan Sebagai Strategi Pembangunan Perdesaan dan Pembangunan Berimbang. Crespent Press, IPB Bogor.

Rondinelli, D., 1985. Applied methods of regional analysis: The spatial dimensions of development policy. London: Westview Press.

Saaty, T.L., 2008. Decision making with the analytic hierarchy process. Int. J. Services Sci., 1: 83-98.

Saaty, T.L., 1993. Decision making for leader: The analytical hierarchy process for decision in complex world. Prentice Hall Coy, Ltd., Pittsburgh.

Sihombing, K., 2008. Pengaruh aglomerasi modal tenaga kerja dan kepadatan penduduk terhadap petumbuhan ekonomi kabupaten demak. Fakultas Ekonomi Undip, Semarang.

Stohr, W.B., 1981. Development from Below. In: Development from Above or Below, Stohr, W.B. and D.R.F. Taylor (Eds.), John Wiley and Sons, New York, ISBN-10: 0471278238.

Sugiyono, 2010. Metode penelitian administrasi: Pendekatan kuantitatif. Kualitatif, dan R\&D. Alfabeta, Bandung.

Sugiyono, 2008. Metode penelitian pendidikan: Pendekatan kuantitatif. Kualitatif, dan R\&D. Alfabeta, Bandung.

Sunariyah, 2003. Pengantar pengetahuan pasar modal. UPP AMP YKPN, Yogyakarta.

Sukirno, S., 1994. Pengantar teori makro ekonomi. Edisi ke-2. PT Raja Grafindo Persada, Jakarta.

Todaro, M.P. and C.S. Smith, 2015. Economic Development. 12th Edn., Pearson Education Limited, Harlow, UK.

Verhej, E.W.M. and R.E. Coronel, 1997. Proses II. Sumber Daya Nabati Asia Tenggara Buah-buahan yang Dapat Dimakan. Gramedia, Jakarta. 